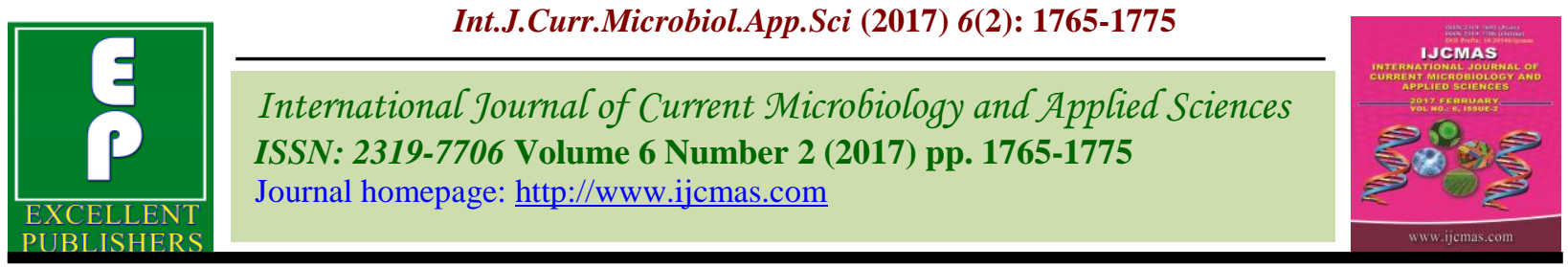

Original Research Article

http://dx.doi.org/10.20546/ijcmas.2017.602.198

\title{
Blooming Behavior of Exotic Apple Cultivars under North Himalayan Region of India
}

\author{
Bilal Ahmad Pandit ${ }^{1}$, Mohammad Shafi Wani ${ }^{1}$, Shahnawaz Ahmad Dar ${ }^{2} *$ \\ and Rizvia Rashid ${ }^{3}$
}
${ }^{1}$ Division of Fruit science, Sher-e-Kashmir university of Agricultural Sciences and Technology of Kashmir, Shalimar-Srinagar 190025 (J\&K), India
${ }^{2}$ Division of Entomology, Sher-e-Kashmir university of Agricultural Sciences and Technology of
Kashmir, Shalimar-Srinagar 190025 (J\&K), India
${ }^{3}$ Division of Bioscience, Sam Higginbottom Institute of Agricultural Technology and Sciences
Allahabad 211007(UP), India
*Corresponding author

\section{A B S T R A C T}

\section{Keywords}

Apple pollination,

Exotic genotypes,

Pollen

compatibility.

Article Info

Accepted:

24 January 2017

Available Online:

10 February 2017
The productivity of apple in Jammu and Kashmir is 8.57 metric tons per hectare, when it is compared with the productivity of developed nations of the world this figure is very low and there is plenty of difference in the productivity. In order to curtail this gap a number of factors has to be reviewed seriously and address them priority wise. The factors of prime importance were identified as compatibility of pollen in apple orchards that actually determines the productivity of this most important fruit crop known as king of temperate fruits. The State Horticulture Department (SHD) has introduced some of the Washington based varieties in the valley to overcome the problem of monoculture of delicious group of varieties. This SHD is supplying planting material of these varieties to the farming community without knowing their pollination status. In this regard division of fruit science SKUAST-K has conducted a research programme during 2012 and 2013 on "Blooming behavior of exotic apple cultivars under north Himalayan region of India" to identify the varieties which bloom early, or mid-season blooming varieties and last to bloom and are compatible with each other. Observation were made to evaluate the difference in response of these Washington brought genotypes under valley conditions and their fruitfulness for horticulture industry of Kashmir. During the studies $1^{\text {st }}$ set of varieties Red Gravenstein, Braeburn and Ginger Gold recorded early pink bud (29.61, 30.28 and 30.38 DARD), initial bloom (35.19, 36.74 and 36.69 DARD), end of flowering (49.23, 50.59 and 49.74 DARD) and petal fall $\left(44.83,46.90\right.$ and 46.44 DARD) respectively. The $2^{\text {nd }}$ set of genotypes Gala Must, Royal Gala, Scarlet Spur, Oregon Spur, Golden Delicious and Red Gold noticed pink bud, initial bloom, end of flowering and petal fall after $1^{\text {st }}$ set. The $3^{\text {rd }}$ set of cultivars Law Red Rome and Early Red One were found to show these stages later than earlier sets.

\section{Introduction}

Over 7,500 apple cultivars are known (Elzebroek and Wind, 2008) and used not only for fresh consumption, but also for consumption as processed materials, such as juice, pie, or cider. Apple and apple products, including juices and extracts, have beneficial effects on Alzheimer's disease, bone health, cognitive decline during normal aging, diabetes, and gastrointestinal protection from drug injury (Hyson, 2011). Apple is the most 
produced fruits in temperate climate areas and is expanding into subtropical and tropical areas (Brown, 2012). However, recent global climate changes manifested in rising temperatures and late frosts in the flowering season caused poorer coloring of apple fruit skin and frost damage to pistils (Sugiura et al., 2007). The central flowers had an intense but short stigmatic activity, whereas lateral flowers had a discrete but much longer stigmatic activity (Losada and Herrero, 2013). As apple (Malus $\times$ domestica) shows gametophytic self and cross-incompatibility, and at least two genetically distinct cultivars are necessary for stable apple production. Therefore, pollination is an important and inseparable component in respect of regular and consistent production in a fruit crop like apple, pollination is of utmost significance and its proportion and magnitude is primarily based upon appropriate selection of varieties (Chauhan et al., 2008). The viability, tube growth and morphological homogeneity related to pollen quality are the most important properties in fruit trees. These properties are useful for plant breeders, geneticists, researchers, development departments and growers (Bolat and Pirlak, 1999).

Apple industry of Jammu and Kashmir State got revolutionized with the introduction of Delicious group, which accounts for about 60 per cent of the total apple production. Fruit industry has become back bone of rural economy and nearly four million people are directly or indirectly involved with this industry, but due to the monoculture, economic returns of the growers have not grown as per their expectations. Therefore, stress is being laid on increasing the compatible varietal spectrum of fruit crops particularly apple. Lately State Horticulture Department has introduced some exotic cultivars of apple which are in bearing at "Advanced Centre for Horticulture
Development Zainapora, Shopian" J\&K, India. Some of these newly introduced varieties have been found to hold promise in terms of productivity, quality and performance under valley conditions. The State Horticulture Department has now started supplying the planting material of these varieties to the farmers of the valley. Of many factors, affecting the fruit production, pollination is of serious importance. It is most critical and complex part of the apple production. Although most of these apple varieties produce abundant bloom but their pollination status is still unknown as no systematic study has been conducted under the valley conditions so far.

\section{Materials and Methods}

The present investigation entitled "Blooming behavior of exotic apple cultivars under north Himalayan region of India" was conducted at 'Advanced Centre for Horticulture Development Zainapora, Shopian Jammu and Kashmir during 2012 and 2013. Full bearing exotic apple cultivars, uniform in age were selected for experimentation in apple orchard. The orchard had proper air drainage which is situated at an altitude of $1600 \mathrm{~m}$ above msl. The soil was moderately deep, having medium fertility status. The soil texture of the experimental farm was sandy loam having soil $\mathrm{pH}$ 6.9, average organic matter, poor phosphorus, normal nitrogen and potassium content. The trees were spaced at $4 \mathrm{~m} \times 4 \mathrm{~m}$ distance and regularly weeded. Fertilizers were applied as per schedule. All recommended package of practices for apple cultivation were followed as per schedule. The experiment was laid in randomized block design with eleven treatments and three replications. Eleven exotic genotypes of apple uniform in age were used for experimentation. Single tree in each variety constituted an experimental unit and each cultivar was replicated three times. The eleven genotypes 
used were Gala Must, Royal Gala, Early Red One, Law Red Rome, Scarlet Spur, Oregon Spur, Braeburn, Ginger Gold, Red Gravenstein, Golden Delicious and Red Gold. These phenological stages were observed visually, when the buds started showing the respective stages like date of initial pink bud stage (pink color at the tip of its leaf scars), date of advanced pink bud stage (when the buds appeared fully pink coloured),date of initial bloom (when about $10 \%$ of flowers opened for each tagged tree),date of final bloom (when about $80-90 \%$ of flowers were open),end of flowering (when experimental unit exhibited 100 per cent of open flowers)and the duration of flowering was worked out as the period (days) between the advanced pink bud and end of flowering in each tagged tree of each cultivar under study for both the years.

The date of occurrences was recorded for each tagged tree for both the years. The dates thus recorded were converted to days after reference date (DARD) fixed arbitrarily as $1^{\text {st }}$ March.

\section{Results and Discussion}

Initial pink bud stage or action threshold for pollination

Among the eleven varieties studied the cultivar law Red Rome took maximum number of 46.58 and 45.57 days after reference date (DARD) to reach the initial pink bud stage followed by Early Red One (42.31 and 39.63 DARD) during both years 2012 and 2013 (given in table 1). The variety Red Gravenstein took minimum days (30.54 and 28.69 DARD) during 2012 and 2013 respectively. The pooled analysis revealed that the differences among one group of varieties i.e. Red Gravenstein, Ginger Gold and Braeburn were statistically at par with each other. The differences among other group of varieties i.e. Gala Must, Royal Gala, Scarlet Spur, Oregon Spur, Golden Delicious and Red Gold were again statistically at par with each other. However, the differences between the two groups were quite significant.

\section{Days to initial bloom stage}

It is evident from the recorded observations that variety Law Red Rome took maximum number of days (52.13 and 50.75 DARD) to reach the initial bloom stage followed by Early Red One (46.50 and 45.47 DARD) as against minimum (36.17 and 34.21 DARD) required by Red Gravenstein during both the years (As given in table 2). However, pooled data revealed that one set of varieties i.e. Braeburn and Ginger Gold were statistically at par with each other, but reflected highly significant difference with other set of varieties i.e. Gala Must, Royal Gala, Scarlet Spur, Oregon Spur, Golden Delicious and Red Gold. The later set of varieties had nonsignificant difference with each other.

\section{End of flowering}

Remarkable differences existed in the data (Table-3) on end of flowering of various exotic cultivars. The variety Red Gravenstein registered minimum number of 50.11 and 48.34 DARD to record end of flowering in comparison to the other varieties followed by Ginger Gold (51.53 and 47.96 DARD) and Braeburn (52.40 and 48.78 DARD) during both 2012 and 2013 years.

The maximum number $(60.45$ and 60.79 DARD) noticed in Law Red Rome, which was significantly superior over other cultivars under study. The pooled data of varieties like Gala Must, Royal Gala, Scarlet Spur, Oregon Spur, Golden Delicious and Red Gold on end of flowering was statistically at par with each other. 


\section{Days to initial petal fall}

The comparison of the data related to the days to initial petal fall (Table-4) reveals that the cultivar Red Gravenstein took minimum number (45.23 DARD) to enter in initial petal fall stage followed by Ginger Gold (47.51 DARD) which was statistically at par with 48.38 DARD recorded in Braeburn cultivar during 2012, the same trend observed during the next year of study. Further, it is evident from the recorded observations that cultivar Law Red Rome required maximum number of days (58.27 DARD) to register the initial petal fall stage during the first year of study and the same trend remained in force for second year of study too. The pooled data shows that there is a significant difference in the initial petal fall stage between all the varieties except Red Gravenstein and Ginger Gold.

\section{Dehiscence of pollen grains}

It is clear from the given data that maximum number of 56.39 and 55.37 DARD required by the cultivar Law Red Rome for dehiscence of pollen grains followed by 50.83 and 49.63 DARD in cultivar Early Red One during 2012 and 2013, respectively. However, the cultivars Gala Must, Royal Gala, Oregon spur, Golden Delicious and Red Gold were at par with each other in the dehiscence of pollen grains during 2012 but in the next year there was non-significant difference between Gala Must and Royal Gala, Scarlet spur and Oregon spur, Golden Delicious and Red Gold.

The minimum number of days required by the cultivar Red Gravenstein (41.37 and 40.12 DARD) followed by Ginger Gold and Braeburn (43.92 and 41.62 DARD) for the dehiscence of pollen grains during 2012 and 2013 respectively. The pooled data was also in tune with observations recorded yearly.

\section{Stigma receptivity percentage}

It is quite evident from the recorded observations in Table-6, that there was a significant difference in the receptivity of stigma with each passing day during five days of study. These investigations further revealed that the stigma became receptive one or two days before anthesis and receptivity lasted until three days after anthesis.

The maximum receptivity of stigma in almost all the cultivars was on the day of anthesis. The pooled data analysis reflects that the highest receptivity 39.05 per cent was recorded in the cultivar Golden Delicious followed by 37.02 per cent in Braeburn cultivar on the day of anthesis, which was however, at par with Red Gold cultivar 36.37 per cent receptivity on the day of anthesis. The minimum receptivity of stigma 28.93 per cent was observed in Red Gold followed by Scarlet spur 30.00 per cent on the day of anthesis.

\section{Initial fruit}

The collected observatory data in the open pollination is penned down in Table-7, which reveals that initial fruit set, was highest 88.35 and 87.00 per cent in Red Gold cultivar followed by Law Red Rome 86.04 per cent and Golden Delicious 86.16 per cent, during the years 2012 and 2013, respectively.

Moreover, the lowest initial fruit set 65.77 and 67.71 per cent noticed in the cultivar Red Gravenstein that was followed by 69.78 and 71.62 per cent in the cultivar Early Red One during 2012 and 2013, respectively. The pooled data revealed that there were significant differences between the varieties except Law Red Rome and Oregon spur that showed non-significant difference. 
Table.1 Initial pink bud stage of exotic apple cultivars

\begin{tabular}{|l|c|c|c|}
\hline \multirow{2}{*}{ Genotypes } & Days After Reference Date (DARD*) & \multirow{2}{*}{ Pooled } \\
\cline { 2 - 3 } & $\mathbf{2 0 1 2}$ & $\mathbf{2 0 1 3}$ & 36.29 \\
\hline Gala Must & 37.28 & 35.31 & 37.57 \\
\hline Royal Gala & 38.66 & 36.48 & 40.97 \\
\hline Early Red One & 42.31 & 39.63 & 46.07 \\
\hline Law Red Rome & 46.58 & 45.57 & 37.18 \\
\hline Scarlet Spur & 38.12 & 36.24 & 36.27 \\
\hline Oregon Spur & 37.52 & 35.01 & 30.28 \\
\hline Braeburn & 31.42 & 29.15 & 30.38 \\
\hline Ginger Gold & 31.71 & 29.05 & 29.61 \\
\hline Red Gravenstein & 30.54 & 28.69 & 36.21 \\
\hline Golden Delicious & 37.31 & 35.11 & 35.18 \\
\hline Red Gold & 36.16 & 34.20 & $\mathbf{0 . 8 8}$ \\
\hline CD (5\%) & $\mathbf{1 . 1 2}$ & $\mathbf{1 . 4 4}$ & \\
\hline (DARD*) Fixed Arbitrarily as $1^{\text {st }}$ March $(2012 \& 2013)$ & \\
\hline
\end{tabular}

Table.2 Initial bloom stage of exotic apple cultivars

\begin{tabular}{|l|c|c|c|}
\hline \multirow{2}{*}{ Genotypes } & \multicolumn{2}{|c|}{ Days After Reference Date (DARD*) } & \multirow{2}{*}{ Pooled } \\
\cline { 2 - 3 } & $\mathbf{2 0 1 2}$ & $\mathbf{2 0 1 3}$ & 42.65 \\
\hline Gala Must & 44.27 & 41.03 & 42.51 \\
\hline Royal Gala & 44.02 & 41.00 & 45.99 \\
\hline Early Red One & 46.50 & 45.47 & 51.44 \\
\hline Law Red Rome & 52.13 & 50.75 & 42.75 \\
\hline Scarlet Spur & 44.19 & 41.31 & 43.02 \\
\hline Oregon Spur & 44.89 & 41.15 & 36.74 \\
\hline Braeburn & 38.35 & 35.13 & 36.69 \\
\hline Ginger Gold & 38.20 & 35.18 & 35.19 \\
\hline Red Gravenstein & 36.17 & 34.21 & 42.75 \\
\hline Golden Delicious & 44.26 & 41.24 & 42.49 \\
\hline Red Gold & 43.81 & 41.17 & $\mathbf{0 . 5 5}$ \\
\hline CD(5\%) & $\mathbf{0 . 8 7}$ & $\mathbf{0 . 7 4}$ & \\
\hline (DARD*) Fixed Arbitrary as $1^{\text {st }}$ March $(2012$ \& 2013) & \\
\hline
\end{tabular}


Table.3 End of flowering of exotic apple cultivars

\begin{tabular}{|l|c|c|c|}
\hline \multirow{2}{*}{ Genotypes } & \multicolumn{2}{|c|}{ Days After Reference Date (DARD*) } & \multirow{2}{*}{ Pooled } \\
\cline { 2 - 3 } & $\mathbf{2 0 1 2}$ & $\mathbf{2 0 1 3}$ & 54.09 \\
\hline Gala Must & 55.50 & 52.68 & 54.15 \\
\hline Royal Gala & 55.58 & 52.73 & 56.36 \\
\hline Early Red One & 56.63 & 56.10 & 60.62 \\
\hline Law Red Rome & 60.45 & 60.79 & 54.13 \\
\hline Scarlet Spur & 55.18 & 53.08 & 54.16 \\
\hline Oregon Spur & 55.28 & 53.04 & 50.59 \\
\hline Braeburn & 52.40 & 48.78 & 49.74 \\
\hline Ginger Gold & 51.53 & 47.96 & 49.23 \\
\hline Red Gravenstein & 50.11 & 48.34 & 53.94 \\
\hline Golden Delicious & 55.38 & 52.51 & $\mathbf{0 . 6 3}$ \\
\hline Red Gold & 55.42 & 52.57 & \\
\hline CD(5\%) & $\mathbf{1 . 0 7}$ & $\mathbf{0 . 7 4}$ & \\
\hline (DARD*) Fixed Arbitrary as 1 $^{\text {st }}$ March $(2012 \& 2013)$ \\
\hline
\end{tabular}

Table.4 Initial petal fall of exotic apple cultivars

\begin{tabular}{|l|c|c|c|}
\hline \multirow{2}{*}{ Genotypes } & \multicolumn{2}{|c|}{ Days After Reference Date (DARD*) } & \multirow{2}{*}{ Pooled } \\
\cline { 2 - 3 } & $\mathbf{2 0 1 2}$ & $\mathbf{2 0 1 3}$ & 50.97 \\
\hline Gala Must & 52.24 & 49.70 & 49.66 \\
\hline Royal Gala & 51.16 & 48.17 & 53.00 \\
\hline Early Red One & 52.73 & 53.28 & 58.35 \\
\hline Law Red Rome & 58.27 & 58.44 & 51.41 \\
\hline Scarlet Spur & 52.42 & 50.41 & 50.65 \\
\hline Oregon Spur & 52.02 & 49.21 & 46.90 \\
\hline Braeburn & 48.38 & 45.43 & 46.44 \\
\hline Ginger Gold & 47.51 & 45.37 & 44.83 \\
\hline Red Gravenstein & 45.23 & 44.43 & 59.54 \\
\hline Golden Delicious & 49.26 & 49.83 & $\mathbf{0 . 6 0}$ \\
\hline Red Gold & 52.29 & 49.43 & \\
\hline CD(5\%) & $\mathbf{0 . 9 0}$ & $\mathbf{0 . 8 5}$ & \\
\hline (DARD*) Fixed Arbitrary as 1 $^{\text {st }}$ March $(2012 \& 2013)$ \\
\hline
\end{tabular}


Table.5 Dehiscence of pollen grains of exotic apple cultivars

\begin{tabular}{|l|c|c|c|}
\hline \multirow{2}{*}{ Genotypes } & Days After Reference Date (DARD*) & \multirow{2}{*}{ Pooled } \\
\cline { 2 - 3 } & $\mathbf{2 0 1 2}$ & $\mathbf{2 0 1 3}$ & 46.84 \\
\hline Gala Must & 48.50 & 45.19 & 46.60 \\
\hline Royal Gala & 48.01 & 44.26 & 50.23 \\
\hline Early Red One & 50.83 & 49.63 & 55.88 \\
\hline Law Red Rome & 56.39 & 55.37 & 46.79 \\
\hline Scarlet Spur & 47.35 & 46.23 & 47.39 \\
\hline Oregon Spur & 48.33 & 46.45 & 43.39 \\
\hline Braeburn & 45.17 & 41.62 & 43.91 \\
\hline Ginger Gold & 43.92 & 43.11 & 40.37 \\
\hline Red Gravenstein & 41.37 & 40.12 & 46.59 \\
\hline Golden Delicious & 48.16 & 45.02 & 47.25 \\
\hline Red Gold & 48.41 & 46.09 & $\mathbf{0 . 7 2}$ \\
\hline CD(5\%) & $\mathbf{0 . 9 8}$ & $\mathbf{1 . 1 3}$ & \\
\hline \multicolumn{2}{|l|}{ (DARD*) Fixed Arbitrary as 1 ${ }^{\text {st }}$ March $(2012 \& 2013)$} & \\
\hline
\end{tabular}

Table.6 Stigma receptivity percentage of exotic apple cultivars

\begin{tabular}{|l|c|c|c|c|c|}
\hline Genotypes & $\begin{array}{c}\text { 2days } \\
\text { before } \\
\text { anthesis }\end{array}$ & $\begin{array}{c}\text { 1day before } \\
\text { anthesis }\end{array}$ & $\begin{array}{c}\text { On the } \\
\text { day of } \\
\text { anthesis }\end{array}$ & $\begin{array}{c}\text { 1days } \\
\text { after } \\
\text { anthesis }\end{array}$ & $\begin{array}{c}\text { 2days } \\
\text { after } \\
\text { anthesis }\end{array}$ \\
\hline Gala Must & 10.88 & 20.89 & $36.46^{*}$ & 18.60 & 9.97 \\
\hline Royal Gala & 6.63 & 20.41 & $35.46^{*}$ & 17.57 & 8.87 \\
\hline Early Red One & 4.77 & 14.73 & $31.38^{*}$ & 13.57 & 5.05 \\
\hline Law Red Rome & 9.15 & 20.23 & $35.09^{*}$ & 18.42 & 9.18 \\
\hline Scarlet Spur & 6.65 & 14.47 & $30.00^{*}$ & 12.94 & 7.07 \\
\hline Oregon Spur & 7.83 & 18.27 & $33.91^{*}$ & 16.42 & 8.30 \\
\hline Braeburn & 11.03 & 20.96 & $37.02^{*}$ & 18.07 & 9.46 \\
\hline Ginger Gold & 8.67 & 17.78 & $34.64^{*}$ & 16.67 & 10.30 \\
\hline Red Gravenstein & 8.69 & 14.76 & $28.93^{*}$ & 9.78 & 7.78 \\
\hline Golden Delicious & 9.80 & 18.99 & $39.05^{*}$ & 17.88 & 8.88 \\
\hline Red Gold & 10.05 & 17.11 & $36.37^{*}$ & 18.06 & 8.51 \\
\hline CD(5\%) & \multicolumn{5}{|l}{} \\
\hline *Peak Receptivity & \multicolumn{5}{|l|}{} \\
\hline
\end{tabular}


Table.7 Initial fruit set (\%) under open pollination of exotic apple cultivars

\begin{tabular}{|l|c|c|c|}
\hline \multirow{2}{*}{ Genotypes } & \multicolumn{2}{|c|}{ Days After Reference Date (DARD*) } & \multirow{2}{*}{ Pooled } \\
\cline { 2 - 3 } & $\mathbf{2 0 1 2}$ & $\mathbf{2 0 1 3}$ & $78.25(8.90)$ \\
\hline Gala Must & $76.74(8.81)$ & $79.76(8.98)$ & $74.83(8.70)$ \\
\hline Royal Gala & $73.02(8.60)$ & $76.65(8.81)$ & $70.70(8.46)$ \\
\hline Early Red One & $69.78(8.41)$ & $71.62(8.52)$ & $84.81(9.26)$ \\
\hline Law Red Rome & $86.04(9.32)$ & $83.58(9.19)$ & $81.48(9.08)$ \\
\hline Scarlet Spur & $80.93(9.05)$ & $82.03(9.11)$ & $82.01(9.24)$ \\
\hline Oregon Spur & $83.80(9.20)$ & $85.03(9.27)$ & $75.38(8.73)$ \\
\hline Braeburn & $81.12(9.06)$ & $82.88(9.15)$ & $66.74(8.23)$ \\
\hline Ginger Gold & $73.94(8.65)$ & $76.83(8.82)$ & $85.18(9.28)$ \\
\hline Red Gravenstein & $65.77(8.17)$ & $67.71(8.82)$ & $\mathbf{0 . 8 4}$ \\
\hline Golden Delicious & $84.20(9.23)$ & $86.16(9.33)$ & \\
\hline Red Gold & $88.35(9.45)$ & $87.00(9.38)$ & $\mathbf{0 . 1 1}$ \\
\hline CD(5\%) & $\mathbf{0 . 1 3}$ & \multicolumn{2}{|c|}{} \\
\hline Square root transformation values given in parenthesis &
\end{tabular}

Initial pink bud stage or action threshold for pollination and Days to initial bloom stage

Initial pink bud stage was first noticed at 29.61 days after reference date (DARD) in the cultivar 'Red Gravenstein' and last of all (46.07 DARD) in the cultivar 'Law Red Rome'. Likewise, date of initial bloom was attained first (35.19 DARD) by 'Red Gravenstein' while 'Law Red Rome' reached at this stage very late (51.44 DARD). The differences in the phenological stages may be due to their genetic differences or the differential chilling requirements of these varieties may be the reason for such variations. Further these varieties may be different in their photo sensitivity and response to temperature resulting in such variations. These results are in consonance with the results of Gasser (1994) who has reported that beginning of blooming depends highly on the site of cultivation. Beginning of bloom can be observed with highest accuracy which indicates the genetic differences among varieties the best. Bodor and Toth (2007) reported that high spring temperature causes shorter blooming period and main bloom takes only few days for the whole cultivar assortment. Soltesz (2002) investigated the stability of the blooming order of varieties in the case of 86 varieties for 20 years and pointed out that beginning of blooming never shows same trend even under similar circumstances. According to him 10 years of observations can be informative but cannot define the place of a variety in the blooming order.

\section{End of flowering and Days to initial petal fall}

In the present study, end of flowering (49.23DARD) was observed first in the cultivar 'Red Gravenstein' and last of all (60.62DARD), in 'Law Red Rome' variety. Initial petal fall (44.83DARD) was noticed first in the cultivar 'Red Gravenstein', and last of all (58.35DARD) in 'Law Red Rome' variety. The final petal fall (55.65DARD) was recorded first of all in the cultivar 'Red Gravenstein' and last of all (70.26 DARD) in 
'Law Red Rome' variety. These differential results may be due to the different requirements of temperature, cultural practices followed and ecological conditions of the cultivars, as the average temperature during bloom period may affect the flowering duration. These results are in conformity with the findings of Facteau et al., (1986) who reported that beginning of flowering; full bloom and end of flowering were two weeks later during 2007 than 2006 year. Such divergent results might be due to the difference between the temperatures during early stage of vegetative development. According to Kronenberg (1985) an eight day difference existed in the bloom time of apple at 119 locations across Europe.

Flowering date and period varies according to cultivar aptitude as well as ecological and cultural conditions. Searle (1965) stated in general that flower induction of photo periodically sensitive plants is controlled by florigen which is produced in leaves and transported to buds. Florigen was described to play a positive role in activating genes or a negative one, blocking gene-repressors. Taburence (1983) found that late flowering in some cultivars may be due to their high chilling requirement.

The apple tree is a monoecious species with hermaphroditic flowers. Sharma and Bist (1987) observed that the low chilling cultivars attained full bloom within 5-10 days after the start of flowering. Suresh and Sharma (1991) observed that the variation in dates of flowering may be attributed to the difference in agro-climatic conditions of a particular place.

\section{Dehiscence of pollen grains and Stigma Receptivity percentage}

Earlier dehiscence of pollen grains (40.74 DARD) was noticed in 'Red Gravenstein' than all other varieties. In the case of Law Red Rome the dehiscence of pollen was very late (55.88 DARD). Dehiscence is the process of producing pollen from anthers or bursting of anthers to produce yellow powdery mass known as pollen grains. In general it took 2-3 days from anthesis of a flower to dehiscence of anthers. The variations in pollen dehiscence and stigma receptivity may be due to the genetic differences between the cultivars or these may be because of some environmental conditions particularly temperature during the flowering period. These results are in conformity with the findings of Aparecida et al., (2004) who reported that temperature is a basic factor in the control of environmental conditions and influences pollen dehiscence, pollen grain germination and longevity. It is quite evident from the recorded observations, that there was a significant difference in the receptivity of stigma with each passing day during five days of study. These investigations further revealed that the stigma became receptive one or two days before anthesis and receptivity lasted until three days after anthesis. The maximum receptivity of stigma in almost all the cultivars was on the day of anthesis. The pooled data reflects that the highest receptivity 39.05 per cent was recorded in the cultivar Golden Delicious followed by 37.02 per cent in Braeburn cultivar on the day of anthesis, which is however, at par with Red Gold cultivar with 36.37 per cent receptivity of stigma on the day of anthesis. The minimum receptivity of stigma 28.93 per cent was observed in Red Gold followed by Scarlet spur 30.00 per cent on the day of anthesis. Stigma receptivity was assessed as the capacity of the stigma to offer support for pollen germination and initial pollen tube growth in the style. In the present study the stigma receptivity at anthesis was more than at two days after anthesis during both the years (Fig. 1). Temperature has been pointed out as one of the main factors interacting with 
flower receptivity, strongly determining stigmatic receptivity, pollen tube growth and ovule development (Sanzol and Herrero, 2001). Under specific conditions flower receptivity is the result of the relative influence of temperature over these parameters.

\section{Fruit set}

The varieties under trial exhibited significant variations in fruit set under open pollination conditions. The variations in fruit set among different varieties may be because of their genetic differences. Fruit set in temperate fruits has been reported to depend upon the prevailing environment during flowering as well as the period following fruit set. In the present study Royal Gala, Early Red One, Scarlet spur, Ginger Gold and Red Gravenstein were found to be completely selfincompatible as these varieties were devoid of any fruit set during both 2012 and 2013 under natural selfing. Sharma et al., (2005) under Nauni conditions observed Gala to be selfcompatible in 2004 but the same cultivar failed to set fruit in 2005 on selfing.

Besides genetic differences there could be an array of reasons for such differences in the initial and final fruit set among the varieties like temperature, weather conditions, the atmosphere which is conducive for bee flight, pollen compatibility, mixture of pollen, effective pollination period of varieties, stigma receptivity, ovule longevity, pollen tube growth, diploid or triploid nature of varieties and post bloom temperature. Moreover, the fruit set behavior is controlled gametophytically by a locus which is a multigene complex; one S-RNase gene is expressed in the pistil and one S-haplotype specific gene in the pollen tubes.

\section{References}

Aparecida, S.P.L., Darlan, R.J., Pasqual, M.,
Carvalho, S.F. and Pereira, J.K. 2004. Receptiveness of the stigma and in vitro germination of orange pollen, submitted to different temperature. Cienc. Agrotech. Lavras, 28(5): 1087 1091.

Bodor, P., Gaal, M. and Toth, M. 2008. Metaxenia in apples cv. 'Rewena', 'Relinda', 'Baujade' as influenced by scab resistant pollinizers. Int. J. Horticultural Sci., 14(3): 11-14.

Bolat, I. and L. Pirlak. 1999. An Investigation on Pollen Viability, Germination and Tube Growthin Some Stone Fruits. Tr. J. Agri. Forestry, 23: 383-388.

Brown, S 2012. "Apple," in Fruit Breeding, M. L. Badenes and D. H.Byrne, Eds., pp. 329-367, Springer, New York, NY, USA.

Chauhan, G., G. Sharma and K.K. Jindal. 2008. Studies on Flowering, Pollination and Fruit Set in Some Apple Cultivars. ENVIS Bulletin: Himalayan Ecol., 16(1): 33- 36.

Elzebroek, A.T.G. and Wind, K. 2008. "Edible fruits and nuts," in Guide to Cultivated Plants.

Elzebroek, A.T.G. and K. Wind, Eds., pp. 25131, CAB International, Wallingford, UK.

Facteau, T., Rove, K. and Chestnut, N. 1986. Firmness of sweet cherry fruit following grow in New York. Proceedings of American Society of Horticultural Sci., 114(9): 776-780.

Facteau, T., Rove, K. and Chestnut, N. 1986. Firmness of sweet cherry fruit following grow in New York. Proceedings of American Society of Horticultural Sci., 114(9): 776-780.

Gasser, H. 1994. Seit 30 Jahren der warmste Marz. Obstbau, 31(5): 155.

Hyson, D.A. 2011. "A comprehensive review of apples and apple components and their relationship to human health," Adv. Nutri., 2(5): 408-420. 
Kronenberg, H.G. 1985. Apple growing potentials in Europe. Flowering dates. Netherland J. Agri. Sci., 33: 45-52.

Losada, J.M. and Herrero, M. 2013. "Flower strategy and stigma performance in the apple inflorescence," Scientia Horticulturae, vol. 150, pp. 283-289.

Sanzol, J. and Herrero, M. 2001. The effective pollination period in fruit trees. Sci. Horticulture, 90: 1-17.

Searle, N.E. 1965. Physiology of flowering. Annual Review of Plant Physiol., 16: 97-118.

Sharma, G., Roshan, A. and Sharma, O.C. 2005. Pollination deceive factor in apple productivity. In: Temperate Horticulture Current Senario. [Eds. D.K. Sharma, S.K. Sharma and K.K. Pramnick].

Sharma, S.K. and Bist, H.S. 1987. Studies on flowering behavior of some low chilling cultivars of apple. Punjab Horticulture J., 26(3-4): 227-233.

Soltesz, M. 2002. Alma. In: Fajtataritas a
Gyumolesultetvenyekben. [Eds. J. Nyeki, M. Soltesz and Z. Szabo]. MezogazdaKiado, Budapest, pp. 72150.

Soltesz, M. 1992. The use of phenological information in determing cultivar combination in apple. D.Sc thesis. Hungarian Academy of Science, Budapest.

Sugiura, T., Kuroda, H. and Sugiura, H. 2007. "Influence of the current state of global warming on fruit tree growth in Japan," Horticultural Res., 6(2): 57263.

Suresh, K. and Sharma, S.D. 1991. Studies on flowering and fruit set aspects in some new introduction of apple. Punjab Horticulture J., 31: 130-134.

Taburence, M.C. 1983. The effect of temperature on flowering date in two apple cultivars. Anales de la Estaction Experimental de Aula Dei, 16(3/4): 341-346.

\section{How to cite this article:}

Bilal Ahmad Pandit, Mohammad Shafi Wani, Shahnawaz Ahmad Dar and Gowhar Ahmad Dar. 2017. Blooming Behavior of Exotic Apple Cultivars under North Himalayan Region of India. Int.J.Curr.Microbiol.App.Sci. 6(2): 1765-1775.

doi: http://dx.doi.org/10.20546/ijcmas.2017.602.198 